\title{
Toxoplasmoz şüpheli hastalarda Toxoplasma gondii seropozitifliğinin kemilüminesan mikropartikül immunolojik test (CMIA) yöntemi ile araştırılması
}

\author{
Investigation of Toxoplasma gondii seropositivity in toxoplasmosis suspected \\ patients by chemiluminescent microparticle immunological test (CMIA)
}

Dilara Yıldırım, Naciye Hilal Büyükboyacı, Sümeyra Bölükbaşı, Şeyma Duman, Berkin Karaman, Elif Kurt, Gizem Nur Çüycü, Erdal Karakaya, Semra Özçelik*

Mikrobiyoloji Laboratuvarı (Dr. D. Yıldırım), Sivas Numune Hastanesi, TR-58040 Sivas, Tip Fakültesi Öğencileri (N. H. Büyükboyacı, S. Bölükbaşı, Ş. Duman, B. Karaman, E. Kurt, G. N. Çüyçü, E. Karakay), Parazitoloji Anabilim Dalı (Prof. Dr. S. Özçelik), Cumhuriyet Üniversitesi Tıp Fakültesi, TR-58140 Sivas

\section{Özet}

Amaç. Toksoplazmoz, Toxoplasma gondii'nin neden olduğu, akkiz ya da konjenital olarak görülebilen paraziter bir hastalıktır. Çalışmada, Sivas Numune Hastanesi Mikrobiyoloji Laboratuarı'na toksoplazmoz şüphesiyle başvuran hastalarda T.gondii seropozitifliğinin retrospektif olarak araştırılması ve sonuçların değerlendirilmesi amaçlanmıştır. Yöntem. Ocak 2012-Ocak 2013 tarihleri arasında toksoplazmoz ön tanısı ile başvuran, yaşları 0-80 arasında olan, 809 hastada kemilüminesan mikropartikül immünolojik test (CMIA) yöntemiyle anti-T. gondii IgG ve IgM seropozitiflikleri araştırılmıştır. Bulgular. IgG ve IgM birlikte incelenen 207 hastanın 1 'inde $(\% 0,6)$ her iki antikor da pozitif bulunmuştur. IgG çalışılan 244 hastanın 86'sında $(\% 35,3)$, IgM çalışılan 772 hastanın ise 5 'inde $(\% 0,7)$ antikor pozitifliği saptanmıştır. Sonuç. Sonuç olarak, toksoplazmoz seroprevalansı izlenmeli ve seronegatif bireyler için önlemler alınmaldır.

Anahtar sözcükler: Toxoplasma gondii, seroprevalans, Kemilüminesan mikropartikül immünolojik test (CMIA), Toxoplasma IgG, Toxoplasma IgM

\begin{abstract}
Aim. Toxoplasmosis, is a parasitic disease can be seen as an acquired or congenital caused by Toxoplasma gondii. In the study, we aimed to determine seroprevalence of the antibodies against $T$ gondii in the patients admitted to Sivas Numune Hospital in a period of one year. Method. Antibody results for Toxoplasma gondii which were assayed with chemiluminescent microparticle immunological test (CMIA) (Abbott-Architect system, Weisbaden, Germany) from the serum samples of the patients with $0-80$ years old who applied to Sivas Numune Hospital's clinics between January 2012-January 2013 were analysed retrospectively. In the study, anti-toxoplasma $\operatorname{IgG}$ and $\operatorname{IgM}$ antibodies were investigated in sera of 809 patients. Results. The rates of Toxoplasma gondii IgM antibodies were found to be $0.7 \%(5 / 772)$ and that of Toxoplasma gondii IgG antibodies $35.3 \%$ (86/244). In only one patient either IgG or IgM antibodies were obtained positive $(0.6 \%-1 / 207)$. Conclusion. As a result, seroprevalence of toksoplasmosis should be monitored and especially for individuals who are seronegative should take precautions.
\end{abstract}

Keywords: Toxoplasma gondii, seroprevalence, Chemiluminescent microparticle immunological test (CMIA) Toxoplasma IgG, Toxoplasma IgM

Geliş tarihi/Received: 26 Temmuz 2013; Kabul tarihi/Accepted: 28 Kasım 2013

*İletişim adresi:

Dr. Semra Özçelik, Parazitoloji Anabilim Dalı, Cumhuriyet Üniversitesi Tıp Fakültesi TR-58140 Sivas. E-posta: sozcelik@ cumhuriyet.edu.tr 


\section{Giriș}

Dünya genelinde yaygın olarak görülen Toxoplasma gondii, insanların da içinde bulunduğu tüm memeli ve kuşları enfekte edebilen zorunlu hücre içi parazitidir. İlk defa 1908 yılında Nicole ve Manceaux tarafindan bir Afrika kemirgeni olan Ctenodactylus gundii'de tespit edilmiştir. Hastalık, immün sistemi sağlam kişilerde sıklıkla asemptomatiktir ve genelde herhangi bir belirti vermeden kişi sağlığına kavuşmaktadır. İmmün sistemi baskın kişilerde ve gebelerde ise ciddi semptomlara neden olabilmektedir. Enfeksiyon kedi dişkılarıyla saçılan ookistlerin toprakta olgunlaştıktan sonra yiyecek ve içeceklerle ağızdan alınması, bradizoit ve doku kisti formlarını içeren etlerin çiğ veya az pişmiş olarak yenilmesi, organ nakli ve kan transfüzyonu gibi yollarla insanlara bulaşabilmektedir. Konjenital toksoplazmoz, hastalığı hamileliği süresince geçiren kadınların bebeklerinde korioretinit, hidrosefali, mikrosefali, zeka geriliği gibi belirtilere ve hatta bebek ölümlerine neden olurken; akkiz toksoplazmoz semptomatik olgularda hafif soğuk algınlığı, ateş, yorgunluk gibi belirtiler gösterir [1]. Enfeksiyonun tanısında $T$. gondii'ye karşı oluşan IgG ve IgM antikorları araştırılmaktadır. Antikorların saptanmasinda, Sabin Feldman Dye test, İmmün Floresan Antikor (IFA), İndirekt hemaglütinasyon (IHA), Kompleman Birleşmesi ve Enzyme Linked Immuno-Sorbant Assay (ELISA) gibi farklı testler kullanılmaktadır. Sabin Feldman Dye test son derece duyarlı ve özgül olmasına rağmen günümüzde laboratuarlarda güvenilir, ekonomik, basit ve kullanışlı bir yöntem olması nedeniyle sıklıkla ELISA tercih edilmektedir [2]. Ayrıca primer enfeksiyonun zamanını saptamada özgül IgG avidite testi de kullanılabilmektedir. Günümüzde kemilüminesan mikropartikül immünolojik test (CMIA) yöntemi de rutin olarak T.gondii tanısında ELISA gibi sıklıkla kullanılan bir yöntemdir. CMIA testinde rekombinant T.gondii antijenleri kullanılmaktadır. Bu antijenler paramanyetik partiküllere yapıştırılır. Hasta serumunda spesifik antikor varsa bu mikropartiküllere tutunur. İkinci adımda da akridinium etiketli konjugat reaksiyona ilave edilmektedir. Elde edilen kemilüminesan reaksiyon bağıl 1şık üniteleri olarak ölçülmektedir.

Dünya genelinde $T$. gondii seropozitifliği \%15-87 arasında değişkenlik göstermektedir [1]. Bu farklılığa coğrafik koşullar, iklim, sosyokültürel düzey, bulaş yolu ve toplumun yaş ortalaması neden olmaktadır. Bu bilgiye uyumlu olarak sıcak ve nemli bölgelerde prevalansın daha yüksek olduğu gözlenmektedir[3].

Çalışmada, Ocak 2012-Ocak 2013 tarihleri arasında Sivas Numune Hastanesi Mikrobiyoloji Laboratuvarı'na toxoplasmosis ön tanısıyla başvuran hastalarda kemilüminesan mikropartikül immünolojik test (CMIA) yöntemiyle $T$. gondii seropozitifliğinin araştırılması amaçlanmıştır.

\section{Gereç ve yöntem}

Çalışmada, Sivas Numune Hastanesi'ne Ocak 2012-Ocak 2013 tarihleri arasında toksoplazmoz ön tanısı ile başvuran yaşları 0-80 arası değişen toplam 809 hastanın kemilüminesan mikropartikül immünolojik test (CMIA) yöntemiyle (Abbott-Architect system, Weisbaden, Germany) retrospektif olarak Toxoplasma IgG ve/veya IgM sonuçları değerlendirildi. Çalışmaya, $653(\% 80,7)$ kadın, 156(\%19,3) erkek hasta alındı. Laboratuarımıza başvuran Toksoplasmoz ön tanılı hastalar; Kadın Hastalıkları ve Doğum, Çocuk Sağlığı ve Hastalıkları, İç Hastalıkları, Enfeksiyon Hastalıkları ve Klinik Mikrobiyoloji ve diğer (Aile Hekimliği, Deri ve Zührevi Hastalıkları, Göz Hastalıkları, Genel Cerrahi) poliklinikler olmak üzere 5 gruba ayrıldı. Hastaların 207'sinde hem IgG hem de IgM, 244 hastada IgG, 772 hastada da IgM çalışılmıştır. Çalışmada, SPSS 15 paket programı ve ki kare testi kullanılarak istatistiksel değerlendirmeler yapılmıştır.

CMIA'da, ilk aşamada serum örnekleri deney sulandırıcıları ve rekombinant $T$. gondii antijeni [P30 (SAG1) ve P35 (GRA8)] ile paramanyetik mikropartiküller birleştirilmektedir. Hasta örneklerinde bulunan antikorlar T.gondii antijeni ile kaplanmış mikropartiküllere tutunurlar. Çalışmada,yıkamadan sonra ikinci aşamada akridinium ile etiketlenmiş anti-insan IgG veya IgM konjugatı (IgG ve IgM kitleri farklıdır) deneye 
eklendi. İkinci yıkama aşamasından sonra ön tetikleyici ve tetikleyici solüsyonları karışıma ilave edildi. Elde edilen kemilüminesan reaksiyon, bağıll 1şık üniteleri (RLU) olarak ölçüldü. Örneklerdeki anti-T.gondii IgG veya IgM miktarları ARCHITECT i System optik sistemleri ile tespit edilen RLU arasında doğrudan bir ilişki bulunmaktadır. Konsantrasyon değerleri $<1,6 \mathrm{IU} / \mathrm{mL}$ olan örnekler nonreaktif, $\geq 3,0 \mathrm{IU} / \mathrm{mL}$ olanlar ise reaktif olarak değerlendirilirken 1,6 ile $<3,0 \mathrm{IU} / \mathrm{mL}$ arasında olan örnekler ise gri alan olarak değerlendirilmiştir.

\section{Bulgular}

Kliniklerden istenilen antikor türüne göre $\operatorname{IgG}$ ve $\operatorname{IgM}$ birlikte yada ayrı olarak bakılmıştır. IgG ve IgM birlikte incelenen 207 hastanın $1(\% 0,6)$ inde her iki antikor da pozitif bulunmuştur. Çalışmada bulunan 809 hastanın 244 (\%69,8)ünde IgG, $772(\% 95,4)$ inde IgM, kemilüminesan mikropartikül immünolojik test (CMIA) yöntemiyle çalışılmıştır. IgG çalışılan 244 kişinin 86'sı (\%35,3), IgM çalışılan 772 hastanın ise 5'i $(\% 0,7)$ pozitif bulunmuştur (Tablo 1-2).

Tablo 1. IgG çalışılan hastalarda Anti-T.gondii-IgG sonuçlarının dağılımı.

\begin{tabular}{lll}
\hline Test sonucu & Sayı & Yüzde $\mathbf{( \% )}$ \\
\hline Negatif & 158 & 64,7 \\
Pozitif & 86 & 35,3 \\
\hline Toplam & $\mathbf{2 4 4}$ & $\mathbf{1 0 0}$ \\
\hline
\end{tabular}

Tablo 2. IgM çalışılan hastalarda Anti-T.gondii-IgM sonuçlarının dağılımı.

\begin{tabular}{lll}
\hline Test sonucu & Sayı & Yüzde(\%) \\
\hline Negatif & 767 & 99,3 \\
Pozitif & 5 & 0,7 \\
\hline Toplam & $\mathbf{7 7 2}$ & $\mathbf{1 0 0}$ \\
\hline
\end{tabular}

IgG ve IgM birlikte bakılan 207 hastanın sadece $1(\% 0,5)$ inde her iki antikor da pozitif bulunmuştur (Tablo3).

Tablo 3. IgG ve IgM birlikte çalışılan hastalarda Anti-T. gondii antikorlarının karşılaştırmalı dağılımı.

\begin{tabular}{lllll}
\hline & & \multicolumn{2}{c}{ IgM } & \multicolumn{1}{c}{ Toplam } \\
\cline { 3 - 4 } IgG & Negatif & Negatif & Pozitif & \\
\cline { 3 - 4 } & Pozitif & $75(\% 36, \%)$ & $1(\% 0,5)$ & $76(\% 36,7)$ \\
\hline Toplam & & $\mathbf{2 0 6}(\% 99,5)$ & $\mathbf{1}(\% \mathbf{0 , 5})$ & $\mathbf{2 0 7}(\% \mathbf{1 0 0})$ \\
\hline
\end{tabular}

IgG çalış1lan toplam 244 hastanın 184'ü kadın olup, bunların \%27'sinde pozitiflik elde edilirken 60 erkek hastada \%8,2 pozitiflik saptanmıştır (Tablo 4). Aradaki fark anlamlı bulunmuştur $(\mathrm{p}<0,05)$.

Tablo 4. Kemilüminesan mikropartikül immünolojik test (CMIA) yöntemiyle saptanan AntiT.gondii IgG antikor sonuçlarının cinsiyete göre dağılımı.

\begin{tabular}{llll}
\hline & \multicolumn{2}{c}{ IgG } & \multicolumn{1}{c}{ Toplam } \\
\cline { 2 - 3 } Kadın & Pozitif & \multicolumn{1}{c}{ Negatif } & \\
\cline { 2 - 3 } Erkek & $66(\% 27,0)$ & $118(\% 48,4)$ & $184(\% 75,4)$ \\
Toplam & $\mathbf{8 6}(\% 8,20)$ & $40(\% 16,4)$ & $60(\% 24,6)$ \\
\hline
\end{tabular}


IgM çalışılan toplam 772 hastanın 618 'i kadın olup, bunların \%0,5'inde pozitiflik elde edilirken 154 erkek hastada \%0,1 pozitiflik saptanmıştır (Tablo5).

Tablo 5. Kemilüminesan mikropartikül immünolojik test (CMIA) yöntemiyle saptanan AntiT.gondii IgM sonuçlarının cinsiyete göre dağılımı.

\begin{tabular}{llll}
\hline & \multicolumn{2}{c}{ IgM } & \multicolumn{1}{c}{ Toplam } \\
\cline { 2 - 3 } Kadın & Pozitif & \multicolumn{1}{l}{ Negatif } & \\
\cline { 2 - 3 } Erkek & $4(\% 0,52)$ & $614(\% 79,5)$ & $618(\% 80,1)$ \\
Toplam & $\mathbf{5 ( \% 0 , 6 5 )}$ & $153(\% 19,8)$ & $154(\% 19,9)$ \\
\hline
\end{tabular}

Çalışılan hastaların kliniklere göre dağılımı incelendiğinde, IgM pozitifliği Kadın Hastalıları ve Doğum kliniğinden $4(\% 0,5)$ hastada, Çocuk Sağlığı ve Hastalıkları kliniğinden $1(\% 0,1)$ hastada saptanmıştır. IgG pozitiflikleri ise en fazla Enfeksiyon Hastalıkları ve Klinik Mikrobiyoloji kliniğinden gelen $36(\% 4,4)$ hastada gözlenmiştir (Tablo 6).

Tablo 6. Kemilüminesan mikropartikül immünolojik test (CMIA) yöntemiyle ile Anti-T. gondii IgG ve IgM sonuçlarının kliniklere göre dağılımı.

\begin{tabular}{|c|c|c|c|c|c|c|c|}
\hline & $\begin{array}{l}\text { CMIA } \\
\text { sonucu }\end{array}$ & $\begin{array}{l}\text { Kadın hastalıkları } \\
\text { ve doğum }\end{array}$ & $\begin{array}{l}\text { Çocuk sağlığı } \\
\text { ve hastalıkları }\end{array}$ & İç hastalıkları & $\begin{array}{l}\text { Enfek. hast. ve klinik } \\
\text { mikrobiyoloji }\end{array}$ & Diğer & Toplam \\
\hline \multirow[t]{2}{*}{ IgG } & Pozitif & $13(\% 15,1)$ & $1(\% 1,2)$ & $22(\% 25,6)$ & $36(\% 41,9)$ & $14(\% 16,3)$ & $86(\% 35,2$ \\
\hline & Negatif & $32(\% 20,3)$ & $6(\% 3,8)$ & $38(\% 24,1)$ & $42(\% 26,6)$ & $40(\% 25,3)$ & $158(\% 64,8$ \\
\hline \multirow[t]{2}{*}{ IgM } & Pozitif & $4(\% 0,9)$ & $1(\% 0,6)$ & $0(\% 0,0)$ & $0(\% 0,0)$ & $0(\% 0,0)$ & $5(\% 0,6)$ \\
\hline & Negatif & $431(\% 99,1)$ & $160(\% 99,4)$ & $62(\% 100)$ & $81(\% 100)$ & $33(\% 100)$ & $\begin{array}{l}767 \\
(\% 99,4)\end{array}$ \\
\hline \multicolumn{2}{|c|}{ Toplam } & 480 & 168 & 122 & 159 & 87 & 1013 \\
\hline
\end{tabular}

\section{Tartışma}

Tüm dünyada yaygın olarak bulunan, T. gondii'nin yol açtığı toxoplasmosis, insan vücudundaki tüm hayati organları tutabilen özellikle akut dönemde kan, beyin omurilik sıvısı (BOS), meni gözyaşı, tükürük gibi sıvısal çıkartılarda bulunabilen transplasental bulaş ile kalıcı fetal yıkımlara, düşüklere yol açan bir zoonozdur. Toksoplazmoz, immün sistemi sağlam olan kişilerde genellikle (\%90) asemptomik iken, immün sistemi sağlam olmayan kişilerde (AIDS, hematolojik kanserler, kemik iliği ve soliter organ nakli vs.) ağır seyretmekte ve kontrol altına alınmadığında ölümle sonuçlanabilmektedir [1].

T. gondii'ye özgü antikor prevalansının toplumun yaşı ile doğrudan bağlantılı olarak artış göstermesi, hastalığın tüm yaşam boyunca geçirilebilmesine bağlanmaktadır. Hastalığın insidansında görülen farklılık, coğrafi özelliklere, toplumların beslenme alışkanlıklarına, iklime, kediyle olan temasa paralellik göstermektedir. Kedi populasyonunun çok olduğu, az pişmiş ya da çiğ et yenilen 1lıman ve nemli bölgelerde insidansın daha yüksek olabileceği belirtilmiştir [1].

Yurdumuzda toksoplazmoz seroprevalansını saptamak amacıyla yapılan çalışmalarda farklı yöntemlerle (IHA, IFAT, ELISA,PT-PCR gibi) antikorlar araştırılmıştır [3-9]. Rutin olarak birçok hastanede kullanılan CMIA ile ilgili bir değerlendirme bildirilmemiştir. Bu çalışmada, kemilüminesan immünolojik testle elde edilen sonuçlar sunulmuştur.

Toksoplazmozun seroprevalansına yönelik çalışmaların bazılarında toksoplazmoz şüpheli ya da ön tanılı hastalar [9-12], bazılarında ise kadınlar ve/veya doğurgan çağdaki gebe kadınlar ele alınmıştır [3-5, 7, 8, 13-17]. Bütün bu çalışmalardan saptanan ortak bulgu, toplumumuzda Anti-T. gondii IgG antikorlarının pozitifliği yönünden önemli farklılıkların bulunmamasıdır. 
Toksoplazmoz prevalansını iklim, halkın yeme içme ve hayvan besleme alışkanlıkları önemli ölçüde etkilemektedir. Sivas soğuk bir iklime sahip olmakla birlikte kırmızı et tüketimi oldukça fazladır, çiğ etle yapılan ve tüketilen yiyecekler sevilerek yenilebilmektedir. $\mathrm{Bu}$ nedenle daha önce yapılan çalışmalarda olduğu gibi şimdide seroprevalans yüksek bulunmuştur [9].

Duran ve ark. [5]'larının 2002'de Sivas'ta yapmış olduğu TORCH sonuçlarının değerlendirilmesi ile ilgili çalışmada, anti-T.gondii IgG pozitiflik oranlarının yaş gruplarına göre anlamlı bir farklılık gösterdiği, yaş artıkça pozitifliğin arttığ belirtilmiştir. Çalışmada, toplumda konjenital enfeksiyon açısından risk oluşturan bireylerin doğurganlık çağındaki seronegatif kadınlar olduğuna dikkat çekilmiştir. Toplumumuzda özellikle IgG seropozitifliklerinin ortalama \%40-50 olduğu bildirildiği için toplumun yaklaşık yarısının Toxo IgG açısından seronegatif olduğu gerçeği vurgulanmıştır. Bu nedenle risk altındaki seronegatif gebe kadınlarda maliyetler de göz önüne alınarak, T. gondii taramasının ve izlenmesinin gerekliliği vurgulanmıştır.

Yurdumuzun Doğu bölgelerinde yapılan çalışmalarda ise Yiğit ve ark. [10]'ları Erzurum'da anti-Toxoplasma IgG antikorlarını \%24, IgM antikorlarını \%0,4 pozitif olarak, Gül ve ark. [11]'ları Diyarbakır'da IgG antikorlarını \%32,9 ve IgM antikorlarını \%8,16 pozitif olarak bildirmişlerdir. Elazığ'da Aşçı ve ark. [12]'larının 1989-1993 yıllarını kapsayan bir çalışmasında 1614 hastanın \%41'inde anti-Toxoplasma IgG antikorları \%1,8 IgM anti-antikorları pozitif olarak bulunmuştur. Batı bölgelerinde yapılan çalışmalarda ise Polat ve ark. [8]'ları İstanbul'da 2002 yılında yayınladığ 428 gebenin değerlendirildiği bir çalışmada anti-Toxoplasma IgG pozitiflik oranını \%43 ve IgM oranını da \%0,7 olarak bildirmişlerdir. Güngör ve ark. [17]'ları 1999 yılında Ankara'da yaptığı çalışmada 245 gebede Sabin Feldman ve ELISA yöntemiyle antiToxoplasma antikorlarını çalışmış, $T$. gondii IgG pozitiflik oranını \%41,6 olarak saptamışlardır. Gebelerin rutin olarak toksoplazmoz açısından araştırılması gerektiği sonucuna varılmıştır.

$\mathrm{Bu}$ çalışmada da yaşları 0-80 arasında değişen 809 hasta çalışmaya alınmıştır. Kliniklerden istenilen antikor türüne göre $\operatorname{IgG}$ ve $\operatorname{IgM}$ birlikte yada ayrı olarak bakılmıştır. IgG ve IgM birlikte incelenen 207 hastanın 1'inde $(\% 0,6)$ her iki antikor da pozitif bulunmuştur. Çalışmaya alınan 809 hastanın 244'ünde $(\% 69,8) \mathrm{IgG}, 772$ 'sinde $(\% 95,4)$ IgM kemilüminesan mikropartikül immünolojik test (CMIA) yöntemiyle çalışılmıştır. IgG çalışılan 244 kişinin 86 's $1(\% 30,2)$ pozitif çıkmıştır. IgM çalış1lan 772 hastanın ise 5'i $(\% 0,6)$ pozitif bulunmuştur. IgG çalışılan toplam 244 hastanın 184'ü kadın olup, bunların \%27'sinde pozitiflik elde edilirken 60 erkek hastada \%8,2 pozitiflik saptanmıştır. Sonuçlar, daha önce Sivas'ta yapılan seroprevalans çalışmalarıyla, farklı testler kullanılmış olmasına rağmen benzerlik göstermiştir.

ABD'de yapılan bir çalışmada ise 12 yaş ve üzeri 27 bin 145 kişinin $\% 75$ 'i ile görüşülüp hikayeleri alınmış ve \%65'inde anti-T. gondii antikorları ELISA yöntemiyle aranmıştır. Seroprevalans 30-39 yaş grubunda erkeklerde daha yüksek bulunmuş ancak diğer yaş gruplarında erkek ve kadına arasında bir fark saptanmamıştır. Yine seroprevalans ırka ve etnik gruba göre fark göstermemiştir. Ancak eğitim durumu ve sosyoekonomik düzeye göre farklılık saptanmıştır. Kedi beslemek bazı etnik gruplarda farklılık gösterirken diğerlerinde fark göstermemiştir. Yine bulaş riski olan işlerde çalışanlarda ise yüksek bulunmuştur. Çalışmada T. gondii seroprevelansı \%22,5 bulunmuştur [18].

Daha önce yayınlamış olduğumuz çalışmada, Sivas'taki bir başka hastaneye ait sonuçlar değerlendirilirken, bulguların kliniklere göre dağılımı araştırıldığında en fazla pozitifliğin Kadın hastalıkları ve Doğum kliniğinden saptandığını, özellikle IgM pozitifliğinin de bu klinikten belirlendiği bildirilmişti [9], bu çalışmada ise çalışılan hastaların kliniklere göre dağılımı incelendiğinde IgM pozitifliği Kadın Hastalıları ve Doğum kliniğinden gelen 4 $(\% 0,5)$ hastada ve Çocuk Sağlığı ve Hastalıkları'ndan gelen $1(\% 0,1)$ hastada saptanmıştır. IgG pozitiflikleri ise en fazla Enfeksiyon Hastalıkları ve Klinik Mikrobiyoloji kliniğinden gelen $36(\% 41,9)$ hastada gözlenmiştir. 
Çalışmamızda, gebelik takibi ve diğer nedenlerle başvuran hastalarda \%30,2 T. gondii-Ig $\mathrm{G}$ antikor pozitifliği bulunmuştur. Elde edilen sonuca göre doğu illeriyle benzerlik gösterirken batı illeriyle farklılık arz ettiği görülmektedir. Bu farklılığın ise doğu ve iç Anadolu illerinde daha fazla çiğ et tüketimine, yaşam tarzına, iklimsel faktörlere, kedi besleme alışkanlıklarına, kullanılan tanı yöntemlerine bağlı olduğu belirtilebilir.

Sonuç olarak, T. gondii seroprevalansı yöremizde halen yüksek düzeyde seyretmeye devam etmektedir. Özellikle negatif antikora sahip doğurgan çağdaki kadınların, gebelerin çĭ̆ et tüketme ve kedi besleme alışkanlıklarından vazgeçmesi gerekmekte, sahipsiz kedilerin sahiplendirilmesi ve tedavi edilmesi de toplum sağlığı açısından önem taşımaktadır.

\section{Kaynaklar}

1. Gürüz AY, Özcel MA. Toxoplasmosis. Tıbbi Parazit Hastalıkları içinde; (editör MA Özcel) Meta Basim Matb. İzmir 2007; 141-89.

2. Kuk S, Özden M. Hastanemizde dört yıllık Toxoplasma gondii seropozitifliğinin araştırılması. Türk Parazitol Dergisi 2007; 31: 1-3.

3. İnci M, Yağmur G, Aksebzeci T, Kaya E, Yazar S. Kayseri'de kadınlarda Toxoplasma gondii seropozitifliğinin araştırılması. Türk Parazitol Dergisi 2009; 33: 191-4.

4. Bahar İH, Karaman M, Kırdar S, Yılmaz Ö, Celiloğlu M, Mutlu D. Gebelikte Toxoplasmosis tanisinda anti-Toxoplasma gondii IgM, IgG, IgA antikor ve IgG avidite testlerinin birlikteliği ve önemi. Türk Parazitol Dergisi 2005; 29: 76-9.

5. Duran B, Toktamış A, Erden Ö, Demirel Y, Mamik BA, Çetin M. Doğum öncesi bakımda tartışmalı bir konu: TORCH taraması. C. Ü. Tıp Fak. Dergisi 2002; 24: $185-90$.

6. Aydoğan S, Doğruman Al F, Eren A, Kalkanc1 A, Kuştimur S, Biri A. Toxoplasma gondii infeksiyonu tanısında iki turlu gerçek zamanlı polimeraz zincir reaksiyonu yönteminin kullanılması. Türk Parazitol Dergisi 2005; 29: 80-4.

7. Yazar S, Yaman O, Şahin İ. Toxoplasma gondii seropozitif gebelerde IgG-avidite sonuçlarının değerlendirilmesi. Türk Parazitol Dergisi 2005; 29: 221-3.

8. Polat E, Aslan M, İsenkul R, Aygün G, Aksın N, Çepni İ, Altaş K. Gebe kadınlarda Toxoplasma gondii Ig M ve Ig G antikorlarının ELISA yöntemiyle araştırılması. Türk Parazitol Dergisi 2002; 26: 350-1.

9. Özçelik S, Değerli S, Çeliksöz A, Poyraz Ö. Toxoplazmoz ön tanılı hastalarda T.gondii antikorlarının dağılımı. Türk Parazitol Dergisi 1998; 22: 362-5.

10. Yiğit N, Aktaş AE, Uslu $\mathrm{H}$, Aydın F, Babacan M. Atatürk Üniversitesi Tıp Fakültesi Mikrobiyoloji Laboratuvarına gelen toxoplasmosis şüpheli hasta serumlarında Toxoplasma gondii antikorlarının araştırılması. Türk Parazitol Dergisi 2000; 24: 22-4.

11. Gül K, Dağ MN, Suay A, Mete M, Mete Ö, 1994. D.Ü.Tıp Fakültesinin değişik bölümlerine başvuran ve Toxoplasma ön tanısı konmuş hastalarda Toxoplasma antikorlarının dağılımı. Türk Parazitol Dergisi 1994; 18: 394-7.

12. Aşcı Z, Seyrek A, Kizirgil A, Doymaz MZ, Yılmaz M. Toxoplasma şüpheli hasta serumlarında anti-Toxoplasma gondii IgG ve IgM antikorlarının araştırılması. Türk Parazitol Dergisi 1997; 21: 245-7.

13. Güneş H, Kaya S, Çetin ES, Taş T, Demirci M. Reprodüktif çağdaki kadınlarda Toxoplazmosis seroprevalansı. S.D.Ü. Tip Fak. Derg 2008; 15: 21-4.

14. Kölgelier S, Demiraslan H, Kataş B, Güler D. Gebelerde Toxoplasma gondii seroprevalans1. Dicle Tip Dergisi 2009; 36: 170-2.

15. Tekay F, Özbek E. Çiğ köftenin yaygın tüketildiği Şanlıurfa ilinde kadınlarda Toxoplasma gondii seroprevalans1. Türkiye Parazitoloji Dergisi 2007; 31: 176-9.

16. Ocak S, Zeteroğlu S, Özer C, Dolapcioğlu K, Güngören A. Seroprevalence of Toxoplasma gondii, rubella and cytomegalovirus among pregnant women in southern Turkey. Scan J Infect Dis 2007; 39: 231-4. 
17. Güngör Ç, Özsan M, Karaaslan A. Hamilelerde Toxoplasma total Ig M ve Ig G antikor pozitifliğinin araştırılması. Ankara Üniversitesi Tıp Fakültesi Mecmuası 2000; 53: 91-3.

18. Jones JL, Kruszon-Moran D, Wilson M, McQuillan G, Navin T, McAuley JB. Toxoplasma gondii infection in the United States: seroprevalence and risk factors. Am J Epidemiol 2001; 154: 357-65. 